\title{
Which Self Represents Sapiens? Biological, Psychiatric, Psychological or Religious?
}

Ebrahim Khodadady ${ }^{1 *}$ and Zahra Hosseini Zahani ${ }^{2}$

${ }^{1}$ Academic Member at Ferdowsi University of Mashhad, Iran.

${ }^{2}$ Department of English language, Iran Language Institute, Iran.

*Corresponding author: Ebrahim Khodadady, Academic Member at Ferdowsi University of Mashhad, Iran.

Received date: July 28, 2021; Accepted date: August 17, 2021; Published date: August 28,2021

Citation: Ebrahim Khodadady and Zahra H. Zahani, (2021). Which Self Represents Sapiens? Biological, Psychiatric, Psychological or Religious? J Clinical Research and Reports, 8(5); DOI:10.31579/2690-1919/189

Copyright: () 2021 Ebrahim Khodadady. This is an open access article distributed under the Creative Commons Attribution License, which permits unrestricted use, distribution, and reproduction in any medium, provided the original work is properly cited.

\begin{abstract}
Background: The physical science of biology and social sciences of psychiatry, psychology and religion address "self" as one of their main themes of investigation.

Objective: to find out which self-described by these sciences represents "sapiens" distinguished from all other organisms because of having wisdom.

Methodology: a representative text of biology was chosen and subjected to textual and statistical analyses and contrasted to those of psychiatry, psychology and religion.

Results: Biology, psychiatry and psychology employ the eight-taxon structure of Linnaeus [1] in which wisdom has no role to play and thus "sapiens" are treated as if they were similar, if not the same as, all other species of plants and animals. Religion, however, divides "sapiens" to three types of self-based on whether they exercise their wisdom or not.

Conclusion: Biology, psychiatry and psychology render all selves including "sapiens" subject to life on the earth and justify whatever they do in terms of securing and enjoying it. Religion, however, lifts "sapiens" to the vicegerency of God and holds them responsible for the type of self they choose to become by extending life to hereafter.
\end{abstract}

Key words: life; self; sapiens; schema theory; harmful organisms; living things; psychiatry

\section{Introduction}

Linnaeus [1] was the first biologist who provided humans with a scientific name to distinguish them from all other "living things" or "organisms" [2], i.e., sapiens. Khodadady [3] was also the first scholar who utilized schema as a theory to explain words such as "sapiens" not only from a biological or taxonomical perspective as Linnaeus did but also from linguistic, cognitive and personal or individualistic dimensions. (While words are external and exist in dictionaries what they represent in the mind of a specific person or individual are internal and form that individual's schemata, the plural of schema.)

Upon naming humans as "sapiens" Linnaeus [1] placed them at the lowest level or taxon of a hierarchically organized structure or taxonomy, i.e., species, and related them to other organisms biologically by including them at seven other taxa called genus, family, order, class, phylum, kingdom, and domain. Khodadady [3, 4] argued that Linnaeus' taxonomy represents cognition as materialized in reading comprehension ability. Khodadady also contended that each taxon of cognition stands for a concept, mental image or schema with a number of constituting common and distinctive features through which it not only distinguishes itself but also relates to other taxa in the mind of a specific individual.

Linnaeus [1], for example, used the distinct feature of "wise" or "sapiens" in Latin [5] to distinguish humans from all other organisms. "Sapiens" is, therefore, a biological schema whose "wisdom" distinguishes them as a specific "species" different from all other species such as chimpanzees as another distinct "species". In spite of being a distinct species different from the species of chimpanzees, "sapiens," bear "anatomical resemblance" [6] to chimpanzees and are, therefore, placed together in the cognitive taxa of family represented by the biological schema hominidae (Table 1). 


\begin{tabular}{|l|l|l|l|}
\hline No & $\begin{array}{l}\text { Cognitive } \\
\text { taxa }\end{array}$ & Biological schemata & Constituting features \\
\hline 1 & domain & organisms & humans, chimpanzees, monkeys, bats, frogs, birds, plants, bacteria \\
\hline 2 & kingdom & animals & humans, chimpanzees, monkeys, bats, frogs, birds \\
\hline 3 & phylum & vertebrates & humans, chimpanzees, monkeys, bats, frogs \\
\hline 4 & class & mammals & humans, chimpanzees, monkeys, bats \\
\hline 5 & order & primates & humans, chimpanzees, monkeys \\
\hline 6 & family & hominidae & humans, chimpanzees \\
\hline 7 & genus & Homo sapiens & humans, Neanderthal (extinct) \\
\hline 8 & species & sapiens & wise living things or humans \\
\hline
\end{tabular}

Table 1: Cognitive taxa represented by biological schemata and their constituting features

Although as a biologist Linnaeus [1] did not provide any further elaboration of "sapiens" in terms of wisdom as their distinctive feature, modern biologists do employ "self" as a schema in their writings quite frequently. The present researchers believe that the wisdom in "sapiens" is partly captured by the schema "self" defined as "a set of cognitive [emphasis added] processes concerned with thought and perception" [7]. Furthermore, wisdom, according to Delaney [8], requires "an understanding [emphasis added] of the highest principles of things that functions as a guide for living a truly exemplary human life" (p. 976).

By resorting to cognitive taxa and their representative biological schemata containing distinctive features such as those presented in Table 1 above, the present study was designed and conducted to find out which features of organisms in general and sapiens in particular are represented by the schema "self" in "Life: The science of Biology" [2] as a representative textbook of biology. Four research questions were raised to guide the study.

1. How many features of "self" are used in biology?

2. Which features of "self" have the highest frequency in biology?

3. What schemata do "self" and its features represent the most in biology?

4. Do biology, psychiatry, psychology and religion differ in their classification and explanation of "self" and its features?

\section{Methodology}

\section{Texts}

Following Khodadady and Zahani [9] who chose "Kaplan \& Sadock's Synopsis of Psychiatry: Behavioral Sciences/ Clinical Psychiatry" [10], "Abnormal Psychology," [11], and the Quran as the representative texts of psychiatry, psychology and religion, respectively, the present researchers chose the $10^{\text {th }}$ edition of "Life: The science of Biology" [2] as a representative text to study the schema species represented by the word "self" in biology. The textbook consists of 1442 pages, ten parts and 59 chapters.
In addition to the representative text of biology, the findings of Khodadady and Zahani [9] on the representative texts of psychiatry, psychology and religion were used in this study. Since the scientific evidences of the representative text of religion, i.e., the Quran, have also been referred to in this study to address "self" from a more inclusive perspective, among its various translations, the rendering of Nasr, Dagli, Dakake, Lumbard and Rustom [12] has also been employed and quoted if not specified otherwise.

\section{Procedures}

The PDF file of "Life: The science of Biology" [2] was broken into different sections by utilizing Adobe Acrobat Pro DC version 2015. The title page, table of contents, illustration credits, and index were excluded from any analysis in this study. A table of specifications was developed in Word to specify the page number and the linguistic context, i.e., a single sentence, sentences, or paragraph, of which the words "self" and "selves" formed a part. If a single sentence containing these words and their derivatives was not clear enough, the sentences or paragraphs in which they occurred were analyzed in order to determine the cognitive taxa and biological schemata the words containing "self" addressed.

Table 2 presents sample linguistic contexts analyzed in this study to determine the schemata biology employs to define "self" at various cognitive levels. As can be seen, "self-regulate" in a sentence on page two of the representative textbook provides a distinctive feature of "living organisms" at the highest level of cognition, i.e., domain. Specifying the biological schema represented by "itself", however, requires analyzing two sentences on page 637 to treat it as a distinctive feature of animals. As a biological schema animals represent the second highest level of cognition, i.e., kingdom, in biology. Similarly, two sentences on page 575 must be read together to understand "self-sufficient" as a distinctive feature of plants. As a biological schema plants represent another kingdom of cognition. (Biologists like Collin [13] generally divide organisms as a cognitive domain into three kingdoms represented by the schemata animals, plants and micro-organisms.)

\begin{tabular}{|l|l|l|l|}
\hline Page & Linguistic contexts & Biological schemata & Distinctive feature \\
\hline 2 & $\begin{array}{l}\text { Living organisms self-regulate their internal environments, thus } \\
\text { maintaining the conditions that allow them to survive. }\end{array}$ & living organisms & self-regulate \\
\hline 637 & $\begin{array}{l}\text { Air and water often contain small organisms and organic molecules } \\
\text { that are potential food for animals. Moving air and water may carry } \\
\text { those items to an animal that positions itself in good location. }\end{array}$ & animal & Itself \\
\hline 575 & $\begin{array}{l}\text { There is a trend toward reduction of the gametophyte generation in } \\
\text { plant evolution. In the nonvascular land plants, the gametophyte is } \\
\text { larger, longer-lived, and more self-sufficient than the sporophyte. }\end{array}$ & plants & self-sufficient \\
\hline
\end{tabular}

Table 2: The biological schemata addressed by "self" 


\section{Data Analysis}

Following Bussmann [14] the "blank spaces" (p. 1285) appearing before and after the word "self" and its derivatives were used to identify and separate them one by one to compile a corpus. Descriptive statistics were then carried out on the corpus to specify the frequency and types of each word. Chi-square analyses were also carried out to find out whether the biology differed significantly from the fields of psychiatry, psychology and religion in the type of "self" and its derivatives it addresses. All analyses were conducted via IBM SPSS Statistic 24.

\section{Results}

\begin{tabular}{|l|l|l|l|l|l|l|l|}
\hline No & "Self" and its features & $\mathbf{F}$ & $\mathbf{\%}$ & $\mathbf{N o}$ & "Self" and its features & F & \% \\
\hline 1 & antiself & 1 & 0.2 & 22 & self-fertilizes & 1 & 0.2 \\
\hline 2 & herself & 1 & 0.2 & 23 & self-fertilizing & 3 & 0.7 \\
\hline 3 & himself & 7 & 1.6 & 24 & self-incompatibility & 10 & 2.3 \\
\hline 4 & itself & 111 & 25.4 & 25 & self-incompatible & 6 & 1.4 \\
\hline 5 & nonself & 32 & 7.3 & 26 & selfing & 4 & 0.9 \\
\hline 6 & ourselves & 3 & 0.7 & 27 & selfish & 1 & 0.2 \\
\hline 7 & same-as-self & 1 & 0.2 & 28 & self-pollinate & 10 & 2.3 \\
\hline 8 & self & 46 & 10.4 & 29 & self-pollinating & 1 & 0.2 \\
\hline 9 & self-cells & 1 & 0.2 & 30 & self-pollination & 11 & 2.5 \\
\hline 10 & self-assembles & 1 & 0.2 & 31 & self-propagating & 1 & 0.2 \\
\hline 11 & self-awareness & 1 & 0.2 & 32 & self-regenerating & 6 & 1.4 \\
\hline 12 & self-compatibility & 7 & 1.6 & 33 & self-regulate & 1 & 0.2 \\
\hline 13 & self-compatible & 4 & 0.9 & 34 & self-regulation & 1 & 0.2 \\
\hline 14 & self-consumption & 1 & 0.2 & 35 & self-replicate & 1 & 0.2 \\
\hline 15 & self-contained & 4 & 0.9 & 36 & self-replicating & 2 & 0.5 \\
\hline 16 & self-control & 1 & 0.2 & 37 & self-replication & 2 & 0.5 \\
\hline 17 & self-destruct & 2 & 0.5 & 38 & self-sufficiency & 1 & 0.2 \\
\hline 18 & self-extending & 1 & 0.2 & 39 & self-sufficient & 2 & 0.5 \\
\hline 19 & self-feeders & 1 & 0.2 & 40 & themselves & 129 & 29.3 \\
\hline 20 & self-fertilization & 14 & 3.2 & 41 & yourself & 5 & 1.1 \\
\hline 21 & self-fertilize & 3 & 0.7 & & Total & 441 & 100 \\
\hline
\end{tabular}

Table 3: Frequency $(F)$ and percentage (\%) of "self" and its features in biology

"Self" and its features represent 194 biological schemata, 20 most frequent of which are presented in Table 4 to answer the third research question. (Interested readers can contact the corresponding author for the complete list of these schemata.) As can be seen "plants" as the kingdom of cognition had the highest frequency $(71,16.1 \%)$, e.g., Most plants have evolved mechanisms that prevent self-fertilization. "Self" itself represents various cognitive taxa such as the antigens of cognitive species
Table 3 presents "self" and its features in biology. As can be seen, the "self" has the second highest frequency of $46(\mathrm{f}=46,10.4 \%)$ preceded by "themselves" and "itself" as its first and second most frequent features, i.e., $129(29.3 \%)$ and $112(25.4 \%)$, respectively. These results answer the first and second research questions by setting the number of "self" features at 40 and specifying "themselves" and "itself" as its most frequent features. These results partially agree with those of Khodadady and Zahani [9] because "themselves" is not only the first most frequent feature ( $f=129)$ of "self" in biology but also in psychiatry, psychology and religion, i.e., $\mathrm{f}=324,325$, and 77 , respectively.

\begin{tabular}{|c|c|c|c|c|c|c|c|}
\hline No & Biological schemata & $\mathbf{F}$ & $\%$ & No & Biological schemata & $\mathbf{F}$ & $\%$ \\
\hline 1 & plant, plants & 71 & 16.1 & 11 & Leptosiphon & 9 & 2.0 \\
\hline 2 & antigen, antigens & 26 & 5.9 & 12 & action potential & 6 & 1.4 \\
\hline 3 & animal, animals & 19 & 4.3 & 13 & Birds & 6 & 1.4 \\
\hline 4 & organism, organisms & 15 & 3.4 & 14 & DNA & 5 & 1.1 \\
\hline 5 & $\begin{array}{l}\text { sapiens [man, people, taxi drivers, } \\
\text { transplant receivers, you] }\end{array}$ & 13 & 2.9 & 15 & B cells & 4 & 0.9 \\
\hline 6 & Species & 12 & 2.7 & 16 & bacterium, bacteria & 4 & 0.9 \\
\hline 7 & protein, proteins & 11 & 2.5 & 17 & Fungi & 4 & 0.9 \\
\hline 8 & cell, cells & 10 & 2.3 & 18 & Pollen & 4 & 0.9 \\
\hline 9 & molecule, molecules & 10 & 2.3 & 19 & flower, flowers & 3 & 0.7 \\
\hline 10 & immune system & 9 & 2.0 & 20 & Individuals & 3 & 0.7 \\
\hline
\end{tabular}

Table 4: Most frequent biological schemata and the frequency $(F)$ and percentage (\%) with which they were represented by "self" in biology

Biology, psychiatry, psychology and religion share "self" and five of its features as common schemata, i.e., "herself", "himself", "ourselves", "themselves", and "yourself". They do, however, not only bring up 27, 173,33 and three features exclusively, respectively, but also in various combinations with each other resulting in the creation of six representing "sapiens" or people, as the second most frequent $(26,5.9 \%)$, e.g., People with rheumatoid arthritis have difficulty in shutting down a $\mathrm{T}$ cell response to self-antigens. It is followed by the cognitive kingdom of "animals" as the third highest ( $\mathrm{f}=19,4.3 \%)$, e.g., Animals have several ways of defending themselves against pathogens - harmful organisms and viruses that can cause disease. interdisciplinary fields as shown in Table 5. The Chi-square analysis of these common and exclusive features answers the fourth research question and shows that the fields differ significantly from each other in their classification and explanation of "self" and its features, i.e. $\mathrm{X}^{2}=$ 822.242, df $=9, p<.0001$. 


\begin{tabular}{|l|l|l|l|l|l|}
\hline Field of Study & F & \% & Field of Study & F & $\%$ \\
\hline Biology & 27 & 8.6 & Psychiatry \& Psychology & 62 & 19.7 \\
\hline Psychiatry & 173 & 55.1 & Psychiatry, Psychology \& Religion & 1 & 0.3 \\
\hline Psychology & 33 & 10.5 & Psychology \& Religion & 1 & 0.3 \\
\hline Religion & 3 & 1.0 & $\begin{array}{l}\text { Biology, Psychiatry, Psychology } \\
\text { Religion }\end{array}$ & 6 & 1.9 \\
\hline Biology \& Psychiatry & 2 & 0.6 & Total & $\mathbf{3 1 4}$ & $\mathbf{1 0 0 . 0}$ \\
\hline Biology, Psychiatry \& Religion & 6 & 1.9 & & & \\
\hline
\end{tabular}

Table 5: Frequency $(F)$ and percent $(\%)$ of "self" and its 313 features addressed in 10 fields

\section{Discussion}

Biology is the science of organisms because they alone possess the distinctive feature of life. Though the representative text of biology analyzed in the present study, i.e., "Life: The science of Biology" [2], never tells its readers where life comes from or why the organisms have been brought to life, it addresses them in general and "sapiens" in particular by assigning them to eight taxa of cognition, i.e., species, genus, family, order, class, phylum, kingdom, and domain. Although biology deals with the "sapiens" as an important species, it deliberately subsumes them under the cognitive taxa of kingdom represented by plants, animals and microorganisms in order to strip them of their unique wisdom.

Biology, for example, replaces the scientific schema "sapiens" with "man", "people", "taxi drivers", "transplant receivers", and "you". It then describes these general schemata in a way that renders sapiens everything but a "wise self" For elaborating "Animal Reproduction", for example, biology brings up coitus interruptus as a non-technological method of contraception through which "the man withdraws his penis prior to ejaculation with the intention of not depositing sperm into the vagina" It then provides the comment that coitus interruptus "requires self-control, especially by the man", highlighting the fact that it has a "very high failure rate" (p. 898)!

Practicing coitus interruptus by sapiens, however, defies what biology studies as a scientific field, i.e., life. Biology divides all things having life, including sapiens, as selves into two categories, i.e., "self" ( $\mathrm{f}=46,10.4 \%)$ and "nonself" ( $\mathrm{f}=32,7.3 \%)$, having the third and fourth highest frequencies after "themselves" ( $\mathrm{f}=129,29.3)$ and "itself" ( $\mathrm{f}=111,25.4 \%)$ [see Table 3]. Biology also approaches "self" as an action whose accomplishment secures the life of organisms through reproduction. According to Sadava et al [2] "individuals of some species", for example, "regularly fertilize their ovules using their own pollen; they are referred to as self-fertilizing, or selfing, species" (p. 460).

In other words, the life studied by biology allegedly occurs out of blue and scientifically secured through certain instinctual behaviours referred to as self-fertilization ( $\mathrm{f}=14,3.2 \%)$, self-pollination ( $\mathrm{f}=11,2.5 \%)$, selfpollinate $(\mathrm{f}=10,2.3 \%)$, self-regenerating $(\mathrm{f}=6,1.4 \%)$, selfing $(\mathrm{f}=4,0.9 \%)$, self-fertilize ( $\mathrm{f}=3,0.7 \%)$, self-fertilizing ( $\mathrm{f}=3,0.7 \%)$, self-replicating $(\mathrm{f}=2,0.5 \%)$, self-replication ( $\mathrm{f}=2,0.5 \%)$, self-fertilizes $(\mathrm{f}=1,0.2 \%)$, selfpollinating ( $\mathrm{f}=1,0.2 \%)$, self-propagating $(\mathrm{f}=1,0.2 \%)$, and self-replicate ( $\mathrm{f}=1,0.2 \%)$. These findings show that out of 41 features of "self" studied in biology $13(32 \%)$ deal specifically with sexual and non-sexual reproduction of "self" (see Table 3).

If a mature male sapiens enters a mature female why should he withdraw "his penis prior to ejaculation with the intention of not depositing sperm into her vagina" if he knows that their life as "selves" may be secured through this intercourse? Which members of sapiens living with these two male and female selves in the same society should they consider as "self" and which ones should they treat as "nonself? Biology considers itself a physical science which is incapable of answering these questions.

Biology [2] does, for example, declare categorically that "although scientific knowledge allows us to do these things [e.g., to select the sex of our children, to use stem cells to repair our bodies, and to modify the human genome], science cannot tell us whether or not we should do so or, if we choose to do them, how we should regulate them. Such issues are as crucial to human society as the science itself, and a responsible scientist does not lose sight of these questions or neglect the contributions of the humanities or social sciences in attempting to come to grips with them" (p. 14)

Among the social sciences recommended indirectly by biology, psychiatry and psychology deal specifically with "self". Similar to biology, these two sciences approach sex as one of their main themes. As a psychologist, Comer [11], for example, resorted to Freud, a psychiatrist, to claim that "all id instincts tend to be sexual, noting that from the very earliest stages of life a child's pleasure is obtained from nursing, defecating, masturbating, or engaging in other activities that he considered to have sexual ties" (p. 63). In response to questions raised by biology, psychiatry and psychology, however, brush away the centrality of "sex" and suggest following "true self" [15] instead. They seem to be arguing, for example, that as "sapiens" these are the "true selves" who can decide when, how, why and with whom they can have sex with or without coitus interruptus.

The "true self" accepted and advocated by social sciences such as psychiatry and psychology is however, according to Strohminger, Newman and Knob [16], "shall we say, evidence-insensitive. ... claims made on its behalf may completely contradict all available data, as when the hopelessly miserable and knavish are nonetheless deemed good 'deep down'. The true self is posited rather than observed. It is a hopeful phantasm. ... in our view, it is a fiction nonetheless" (p. 7).

Neither biology nor psychiatry and psychology do, therefore, offer any answers to the questions dealing with the wisdom of "sapiens" as a "self" from a scientific perspective. Religion does, however, distinguish and separate "sapiens" from all other "selves" subsumed under the biological schemata of plants, animals and microorganisms in terms of their wisdom. It stems from their two unique features, i.e., having God's psyche (e.g., Q15:29), and their being God's only vicegerents on the earth (e.g., Q2:30; $6: 165)$. The "sapiens" are, however, warned by religion that they have not been given God's psyche and vicegerency to do whatever they want but to be tried as to which of them proves to be "the most virtuous in deed" (Q67:2). The acquisition of these virtues does in fact determine the "self" each "sapiens" prefers to become.

The best or highest virtue which is scientifically known as religious orientation is defined by the Quran as "living in this world and hereafter by seeking and following God as the best model and supporter" [17]. In other words, wisdom will be acquired if a "sapiens" complies what God says and avoids what God forbids. They should, for example, be patient (Q13:22) curb their rage (Q3:134), do whatever they say (Q61:2), give regular charity (Q22:41), and stand out firmly for justice (Q4:135). They should not, however, betray trusts (Q8:27), commit fornication (Q25:68), consume alcohol or gamble (Q5:90), defame or slander people (Q49:11), fabricate a lie against God or deny His signs (Q10:17), fear the blame of any blamer (Q5:54), give money in usury or earn any money in usury 
(Q2:278), help one another toward sin and enmity (Q5:2), and wrong anyone (Q4:29) o name a few.

Instead of adopting a scientific method to examine "sapiens" from a religious perspective biology has joined hands with psychiatry and psychology to render God, the creator of life and death (Q67:2), organismic. According to Sadava et al [2], for example, "the 20 species of priapulids are cylindrical, unsegmented, wormlike animals with a three-part body plan consisting of a proboscis, trunk, and caudal appendage ("tail"). It should be clear from their appearance why they were named after the Greek fertility god Priapus" (p. 665). Any male sapiens having a penis of Priapus (Figure 1) will never, shall it be argued from an instinctive and hedonistic perspective, withdraw it from the vagina of any female he chooses for the very reason of being a god of fertility!

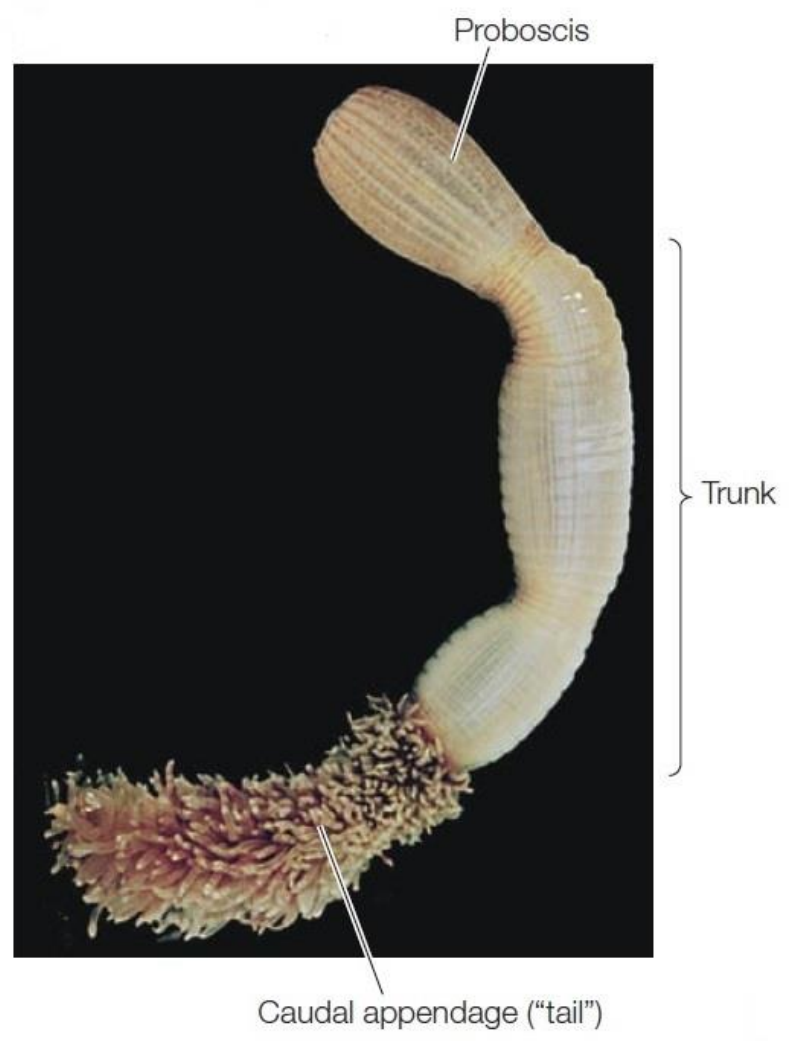

Figure 1: Priapulus caudatus

Biology, psychiatry and psychology do in fact equate "self" with its "life" and indirectly teach all male sapiens to look at themselves as gods and follow none but themselves, if not physical and social scientists! To deify "sapiens" the majority of these scientists, for example, resort to various strategies such as naming some organisms after the Greek fertility god Priapus. Doing so they assume the delusional position of god themselves, i.e., self-theists, and convince others to follow them as polytheists. They justify their delusion by selling the existence of fertility gods as a reality, endorsing having or making penises similar to that of Priapus as indicators of godhood and shouldering off the responsibility of entering and impregnating females as nontechnical! Eulogizing these delusion developers, Harari [18], for example, claimed "We are more powerful than ever before ... Self-made gods with only the laws of physics to keep us company (p. 352).

The delusional nature of Harari's [18] claim that we as sapiens are "selfmade gods" is explained by religion. The Quran, for example, argues that there is no god but one and only one God (e.g., Q37:35; 47:19) because of a number of reasons. He is, for example, the Living and Self-subsisting who never dies (Q2:255). Furthermore, God is the Eternally Sufficient unto Himself. (Q112:2). He begets not; nor is He begotten (Q112:3). And there is none like unto Him (Q112:4). The delusions presented as scientific findings are not confined to fabricating organismic gods and advertising sapiens as "self-made gods". They are extended to what they do as "selves".
The unaccountability of criminal "selves" such as murderers is brought up as a fact or treated as mental disorders in psychiatry and psychology at most because sapiens "are accountable to no one" [18]. A clear and modern example for such criminals is Trump, the former president of America. Being defeated in his second presidential campaign in 2020 he fabricated many lies and incited his supporters to invade the Capitol Hills and stop the approval of his rival, President Biden, as his successor. Trump's supporters injured and killed several people in the process of invasion on January 6, 2021. His second impeachment trial in Senate, however, found Trump not guilty of any crime!

According to religion, Harari's [18] statement that sapiens such as Trump "are accountable to no one" (p. 352) is, nonetheless, a delusion he and almost all biologists, psychiatrists and psychologists believe and support as reality. While they consider "death" as the end of everything including "life", religion argues that "life" in this world is a probationary period during which whatever the sapiens do is recorded in smallest details. It also instructs each and every sapiens to either act as a "vicegerent of God" (Q6:165), i.e., practicing monotheists, or become a self-theist like Trump and polytheists like his supporters if they wish to follow their own desires [9].

Acknowledging the lack of accountability for the majority of self-theists and polytheists as a fact in this world, religion, however, admonishes that in the hereafter they will be held accountable for the type of "self" they 
become. It does, for example, announce categorically that the purpose of life and death is nothing but to evaluate "sapiens' behaviour in this world (Q67:2). While the "life" allows sapiens to choose the self they prefer to be through God's vicegerency, the "death" renders it probationary. It does in fact strip sapiens from whatever abilities they were given in "life" till they are resurrected on the Judgment Day. On this day each self shall see not only a mote's weight of good but also a mote's weight of evil it has done (Q99:7-8). These religious statements do, therefore, imply that sapiens may not be accountable to each other here in this world if they choose to do so. They will, however, be held accountable in the hereafter.

For holding every "self" accountable to God in the hereafter biology, psychiatry and psychology either ignore or oppose religion implicitly. Their opposition goes to such an extreme that they do not even pay attention to scientific findings pointing to the accountability of "self" to God. According to the Torah, for example, the prophet Moses [19] and his brother Aaron were sent by God to deliver the Israelites from the bondage of an Egyptian Pharaoh called Merneptah. He succeeded his father, Ramesses II, who died in "1213 BCE" [20]. Both pharaohs were self-theists who killed many young male Israelites to control their population!

The Quran which was first revealed to the prophet Muhammad in "609/610...CE" [21], i.e., more than 1800 years after Merneptah's death, provides a specific account of his death and foretells a scientific discovery which took place 1289 years after its revelation, i.e., 1898. After the
Pharaoh realizes that he could not ward off the plagues inflicted by God, he allows the Israelites to leave Egypt with Moses. However, very soon the pharaoh and his elites realize that they could not do without the slaves. Gathering a large army the pharaoh chases the Israelites to the Red Sea.

"We [God] carried the Children of Israel across the sea, and Pharaoh and his hosts pursued them out of envy and enmity till, when drowning overtook them, he said, "I believe that there is no god but the One in whom the Children of Israel believe, and I am among those who submit." Now, though previously you disobeyed and were among the workers of corruption? Today We shall save you in your body that you might be a sign unto those who come after you. Yet many among mankind are heedless of Our signs" (Q10:90-92).

The mummified body of Pharaoh Merneptah was discovered by Loret in 1898 at Thebes in the Kings' Valley. He was transported to Cairo where Elliot Smith removed its wrappings on the 8th of July, 1907. Smith later provided a detailed description of this operation and the examination of the body in his book "The Royal Mummies" [22]. In June 1975, along with a team of various expertises Dr. Maurice Bucaille, a medical doctor and surgeon by profession, was allowed to examine the parts of the Pharaoh's body that had been covered until then (Figure 2). He concluded that Merneptah "most probably died either from drowning, according to the Scriptural narrations, or from very violent shocks preceding the moment when he was drowned-or both at once" [23].

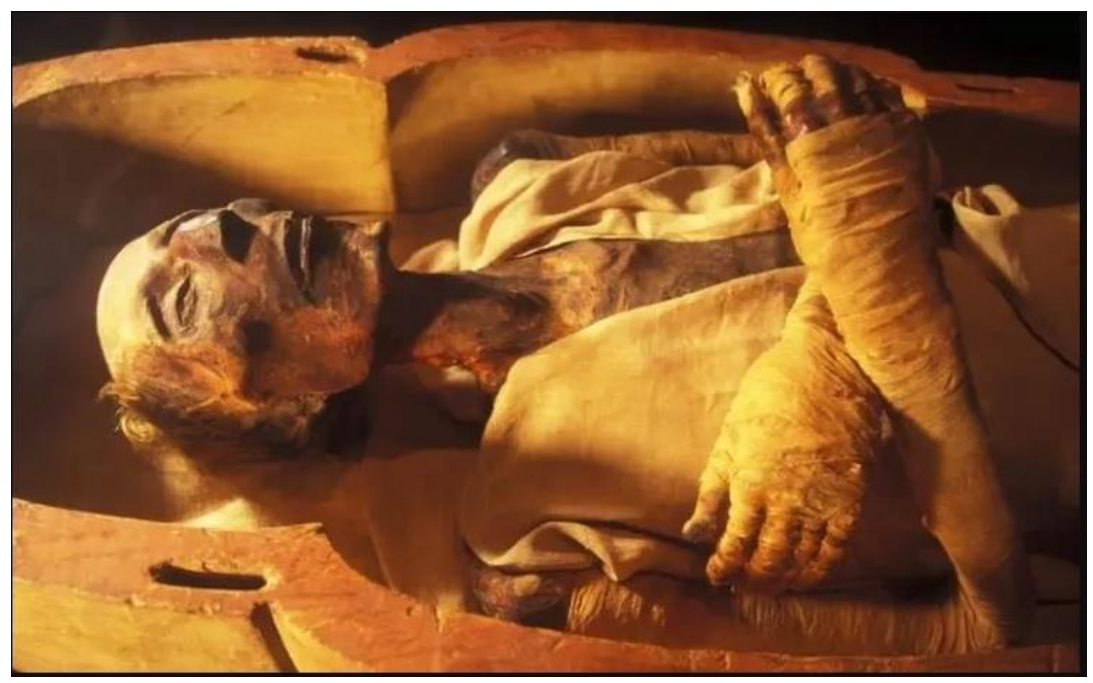

Figure 2: Merneptah's body examined by Dr. Maurice Bucaille in 1975

\section{Conclusion}

Biology, psychiatry and psychology call humans "sapiens" [1] and study them as the lowest taxon of a hierarchically organized structure whose highest taxon consists of living things such as chimpanzees, trees and bacteria having "life" as a common constant. Religion, however, approaches "sapiens" as "God's vicegerents" (Q2:30; 6:165; 10:14; $35: 39)$ whose psyche not only sets them apart from but also gives them control and mastery over all the living things. In spite of being distinct and separate from all living things, "sapiens", according to religion, share "life" with them not as a constant but as a variable for "a term appointed" (e.g., Q29:53).

The variable of life for some species of living things is, however, so important that in order to secure it they do whatever they can including "selfing", i.e., "regularly fertilize their ovules using their own pollen" [2]. Similarly, some "sapiens" commit "selfing" or "incest" along with other behaviours such as exploiting and killing the innocent fellow "sapiens" for many reasons including that of depriving others of their life. Neither psychiatry nor psychology, however, holds these "sapiens" responsible for what they have done. They are at most treated as mentally disordered if they failed in escaping the so called human justice.

Religion, nonetheless, treats the life of "sapiens" not as an end in itself as biology, psychiatry and psychology do, but as a temporary and appointed period of time on the earth during which the "sapiens" can exercise their wisdom consciously and freely to become self-theists, polytheists or practicing monotheists [9]. With death the period ends after which these three selves will be held accountable for what they have done. In order to provide an objective example and show what will happen to self-theists and their polytheistic followers here on this earth, religion relates the case of an Egyptian Pharaoh called Merneptah. His body was discovered by modern "sapiens" after his death more than 3000 years ago and his being drowned was confirmed by medical experts as foretold in the Quran when it was revealed 1400 years ago to the prophet Muhammad. 
In contrast to self-theists like Merneptah and polytheists like his followers, religion announces that the practicing monotheists such as Moses, Jesus and Muhammad as well as their followers achieve perpetual life and bliss after their worldly death, e.g., "deem not those slain in the way of God to be dead. Rather, they are alive with their Lord, provided for" (Q3:169). In other words, by following God, "sapiens" acquire some of His attributes such as "wisdom" (e.g., Q3:6) here in this world and "perpetual life" (Q2:255) in the hereafter. The present researchers believe that acquiring perpetual life or complete health is the ultimate goal of all "sapiens" sought through sciences such as medicine, psychiatry, psychology and religion.

\section{Declarations}

\section{Conflict of interest: None}

\section{Funding: None}

\section{References}

1. Linnaeus C. (1735). Systema naturae, per regna tria naturae, secundum classes, ordines, genera, species, cum characteribus, differentiis, synonymis, locis. Typis Ioannis Thomae

2. Sadava, D., Hillis, D. M., Heller, H. G., \& Berenbaum, M. R. (2014). Life: The science of biology $\left(10^{\text {th }}\right.$ ed.). Sunderland, MA: Sinauer Associates.

3. Khodadady, E. (1997). Schemata theory and multiple choice item tests measuring reading comprehension. (Unpublished doctoral dissertation). The University of Western Australia, Australia.

4. Khodadady, E. (2013). Research principles, methods and statistics in applied linguistics. Mashhad: Hamsayeh Aftab.

5. Biggs, A., Hagins, W. C., Kapicka, C., Lundgren, L., Rillero, P., Tallman, K. G., ... Johnson, R. (2004). Biology: The dynamics of life. Columbus, $\mathrm{OH}$ : McGraw-Hill.

6. Lapedes, D. N. (Ed.). (1978). Dictionary of scientific and technical terms ( $2^{\text {nd }}$ ed.). New York: McGraw-Hill.

7. Schultz, D. P., \& Schultz, S. E. (2013). Theories of personality (10th ed.). Belmont, CA: Wadsworth.

8. Delaney, C.F. (1999). Wisdom. In R. Audi (Ed.), The Cambridge Dictionary of Philosophy (2nd ed. p. 976). Cambridge: Cambridge University Press.
9. Khodadady, E., \& Zahani, Z. H. (2021). Self in psychiatry, psychology and religion: Textual analysis. Psychology and Psychotherapy: Research Studies. 4(5), 1-9.

10. Sadock, B. J., Sadock, V. A., \& Ruiz, P. (2015). Kaplan \& Sadock's synopsis of psychiatry: Behavioral sciences/clinical psychiatry (11th ed.). Philadelphia, PA: Wolters Kluwer.

11. Comer, R. J. (2015). Abnormal psychology (9th ed.). New York, NY: Worth Publishers.

12. Nasr, S. H., Dagli, C. K., Dakake, M. M., Lumbard, J. E. B., \& Rustom, M. (Eds.). (2015). The study Quran: New translation with notes and commentary. New York, NY: Harper one. Retrieved from.

13. Collin, S. (2007). Dictionary of science and technology (2nd ed.). London: A \& C Black.

14. Bussmann, H. (1996). Dictionary of language and linguistics (G. Trauth \& K. Kazzazi, trans.). London: Routledge.

15. Winnicott, D. W. (1960). Ego distortion in terms of true and false self. In D. W. Winnicott (1965). The Maturational Processes and the Facilitating Environment: Studies in the Theory of Emotional Development (pp. 140-153). New York: International Universities Press.

16. Strohminger N., Newman, G., and Knobe, J. (in press). (2017). The True Self: A psychological concept distinct from the self. Perspectives on Psychological Science, 1-11.

17. Khodadady, E., \& Dastgahian, B. S. (2020). A scripture-specific religious orientation scale: Development and validation. Journal of Psychology and Mental Health Care, 4(1), 1-13.

18. Harari, Y. N. (2014). Sapiens: A brief history of humankind. Canada: McClelland \& Stewart.

19. Berlin, A. (1996). Moses. In P. J. Achtemeier (ed.), the Harper Collins Bible Dictionary (Rev. ed.) (pp. 704-8). New York: Harper Collins.

20. Mark, J. J. (2009, September 02). Ramesses II. World History Encyclopedia.

21. Carimokam, S. (2010). Muhammad and the people of the book. United States of America: Xlibris Corporation.

22. Smith, E. (1912/2000). The royal mummies. London: Gerald Dukworth.

23. Bucaille, M. (1987). The Bible, the Quran and science: The Holy Scriptures examined in the light of modern knowledge (A. D. Pannell, Trans.).

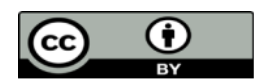

This work is licensed under Creative Commons Attribution 4.0 License
Ready to submit your research? Choose Auctores and benefit from:

$>$ fast, convenient online submission

$>$ rigorous peer review by experienced research in your field

$>$ rapid publication on acceptance

$>$ authors retain copyrights

$>$ unique DOI for all articles

$>$ immediate, unrestricted online access

At Auctores, research is always in progress.

Learn more https://auctoresonline.org/journals/journal-of-clinicalresearch-and-reports 